\title{
Benefit of Adjuvant Chemotherapy in Node-Negative T1a Versus T1b and T1c Triple Negative Breast Cancer
}

Genevieve A Fasano ( $\square$ gaf9034@med.cornell.edu )

Weill Cornell Medicine https://orcid.org/0000-0002-6555-400X

Solange Bayard

Weill Cornell Medicine

Yalei Chen

Henry Ford Health System

Leticia Varella

Weill Cornell Medicine

Tessa Cigler

Weill Cornell Medicine

Rache Simmons

Weill Cornell Medicine

Alexander Swistel

Weill Cornell Medicine

Jennifer Marti

Weill Cornell Medicine

Anne Moore

Weill Cornell Medicine

Eleni Andreopoulou

Weill Cornell Medicine

John $\mathbf{N g}$

Weill Cornell Medicine

Andrew Brandmaier

Weill Cornell Medicine

Silvia Formenti

Weill Cornell Medicine

Haythem Ali

Henry Ford Health System

Melissa Davis

Weill Cornell Medicine

Lisa Newman 
Weill Cornell Medicine https://orcid.org/0000-0003-2059-0477

\section{Research Article}

Keywords: triple negative, node-negative, breast cancer, adjuvant chemotherapy

Posted Date: June 21st, 2021

DOI: https://doi.org/10.21203/rs.3.rs-625370/v1

License: (c) (i) This work is licensed under a Creative Commons Attribution 4.0 International License. Read Full License

Version of Record: A version of this preprint was published at Breast Cancer Research and Treatment on January 13th, 2022. See the published version at https://doi.org/10.1007/s10549-021-06481-4. 


\section{Abstract}

Purpose: National Comprehensive Cancer Network guidelines recommend delivery of adjuvant chemotherapy in node-negative triple negative breast cancer (TNBC) if the tumor is $>1 \mathrm{~cm}$ and consideration of adjuvant chemotherapy for $\mathrm{T} 1 \mathrm{~b}$ but not $\mathrm{T} 1 \mathrm{a}$ disease. These recommendations are based upon sparse data regarding the role of adjuvant chemotherapy in T1a and T1b node-negative TNBC. Our objective was to clarify the benefits of chemotherapy for patients with T1N0 TNBC, stratified by tumor size.

Methods: We performed a retrospective analysis of survival outcomes in an IRB-approved prospectivelymaintained database of TNBC patients treated at two academic institutions in the United States from 1999-2018. Primary tumor size, histology, and nodal status were based upon definitive surgical pathology. Mean follow-up was 5.3 years.

Results: 756 TNBC cases were analyzed; 258 T1N0 TNBC patients were identified. Adjuvant chemotherapy was delivered to $30.5 \%$ of $\mathrm{T} 1 \mathrm{a}, 64.7 \% \mathrm{~T} 1 \mathrm{~b}$, and $83.9 \% \mathrm{~T} 1 \mathrm{c}(\mathrm{p}<0.0001)$. Factors associated with delivery of adjuvant chemotherapy were age, histology, high-grade disease, and postoperative adjuvant radiation therapy. At a mean follow-up of 5.3 years, increase in overall survival was associated with use of chemotherapy in patients with T1c disease $(93.2 \% \mathrm{v} .75 .2 \% \mathrm{p}=0.008)$ but not in those with T1a $(100 \%$ v. $100 \% p=0.3778)$ or T1b $(100 \%$ v. $95.8 \% p=0.2362)$ disease.

Conclusion: Our data support current guidelines indicating benefit from adjuvant chemotherapy in nodenegative TNBC associated with T1c tumors but excellent outcomes were observed in cases of T1a and T1b disease, regardless of whether adjuvant chemotherapy was delivered.

\section{Introduction}

Most early stage, node-negative breast cancer patients face an excellent outcome with appropriatelyselected locoregional and systemic therapy. Triple negative breast cancer (TNBC) represents a high-risk phenotype associated with a more advanced stage distribution and higher mortality rates compared to non-TNBC, even when detected early. Chemotherapy is the standard systemic treatment offered for TNBC and because these tumors tend to be biologically more aggressive, the threshold for offering adjuvant chemotherapy to node-negative patients is lower for TNBC compared to non-TNBC patients. However, the minimum tumor size for which a node-negative TNBC patient should be routinely offered adjuvant chemotherapy has not yet been definitively established.

Retrospective analyses suggest that TNBC patients with node-negative disease and primary tumors no larger than one centimeter achieve excellent 5-year locoregional and distant control, regardless of whether they receive adjuvant chemotherapy [1-3]. In contrast, others have shown that adjuvant chemotherapy is associated with improved outcomes even among cases of sub-centimeter disease [4]. Robust data regarding outcomes for T1 bNO TNBC are sparse, because of challenges with regard to early detection of TNBC. 
Adjuvant chemotherapy is included as standard treatment in 2020 National Comprehensive Cancer Network (NCCN) management algorithms for all node-positive TNBC and for node-negative TNBC when the primary tumor is larger than one centimeter. NCCN guidelines are ambiguous for cases of nodenegative T1b TNBC, with a recommendation that adjuvant chemotherapy be "considered"; adjuvant chemotherapy is not recommended for T1aN0 disease. In view of chemotherapy toxicity, cost, and risk of overtreatment, we sought to review our experience by investigating the survival benefits associated with adjuvant chemotherapy among women diagnosed with node-negative T1 TNBC stratified by tumor size.

\section{Methods}

\section{Patient Population}

The study design and data collection methods were approved by the Weill Cornell Medicine (WCM) and Henry Ford Health System (HFHS) Institutional Review Boards. HFHS includes patients treated at two sites in metropolitan Detroit, Michigan and WCM includes patients treated at two sites in Manhattan, New York. We reviewed the electronic medical records of TNBC patients seen at WCM and HFHS from December 1999 to June 2018. Patients meeting inclusion criteria for this study were those with pathologically confirmed TNBC defined as immunohistochemistry revealing estrogen receptor $<1 \%$, progesterone receptor $<1 \%$, and HER2/neu immunohistochemistry $(\mathrm{IHC}) 1+$ or 0 ; cases of HER2/neu $2+$ were included if they were negative for amplification by fluorescence in situ hybridization (FISH).

Patients with tumors that were pathologic stage T1N0 (T1a: $>1 \mathrm{~mm}$ but $\leq 5 \mathrm{~mm}$; T1b: $>5 \mathrm{~mm}$ but $\leq 10$ $\mathrm{mm}$; T1c: $>10 \mathrm{~mm}$ but $\leq 20 \mathrm{~mm}$ ), undergoing primary surgical therapy without the receipt of any neoadjuvant treatment were reviewed. Patients with unknown or unverified hormone receptor and/or HER2 status, an incomplete clinical record or those in whom delivery of adjuvant chemotherapy could not be confirmed were excluded. Patient, disease, and treatment characteristics were retrospectively reviewed and entered into a RedCap database. Primary tumors and lymph nodes were staged based on pathology reports according to the American Joint Committee on Cancer's AJCC Cancer Staging Manual.

\section{Statistical Analysis}

The statistical programming language $R$ version 3.6.1 (R Foundation for Statistical Computing) was used. Chi-squared tests assessed association between categorical variables; student's $t$ tests were used to compare difference of continuous variables within groups. The primary endpoints were overall survival, local recurrence free survival, distant recurrence-free survival, and recurrence-free survival. The KaplanMeier plot and the 5-year survival probability was evaluated. Log rank test was used to assess the survival difference between patients who did and did not receive postoperative adjuvant chemotherapy. Multivariable Cox proportional hazards modelling was performed to jointly model the impact of adjuvant chemotherapy and adjuvant radiotherapy on overall survival. Survival data were censored at 15 years.

\section{Results}




\section{Patient Characteristics}

We identified 756 TNBC cases at WCM and HFHS. Clinicopathologic characteristics of the 282 patients with T1N0 disease at each site are shown in Table 1. With regard to the two study sites, the population at HFHS was comprised of more African American patients compared to WCM, reflecting differences in the population demographics of metropolitan Detroit compared to Manhattan. There were also differences between the two sites with regard to histology; however, at both sites the majority of patients had invasive ductal carcinoma. A higher proportion of high-grade disease was seen at WCM than at HFHS (81.31\% v. $71.43 \% ; p=0.048$ ). Additionally, patients at WCM were more likely to undergo contralateral prophylactic mastectomy than at HFHS (19.19\% v. 4.76\%; $p=0.00357)$. Among the 282 T1NO TNBC patients, the receipt of adjuvant chemotherapy was unknown for 24; therefore, a total of 258 patients comprised the final study population. Mean follow-up was 5.3 years (median 4.7 years; range $<1$ month to 15.0 years). Median age was 62 years (range $29-92)$. More than half of patients $(137 ; 53.1 \%$ ) had T1c tumors, with 36 (13.9\%) having T1a and 85 (32.9\%) having T1b disease.

\section{Factors Associated with Delivery of Adjuvant Chemotherapy}

Among T1N0 TNBC patients ( $n=282)$, adjuvant chemotherapy was delivered to $30.5 \%$ of T1a, $64.7 \%$ T1b, and $83.9 \%$ T1c $(p<0.0001)$. Factors associated with delivery of adjuvant chemotherapy were age $\leq 50$ years $(84.4 \%$ v. $65.5 \% p=0.007)$, histology $(p=0.0337)$, high-grade disease $(75.1 \%$ v. $51.0 \% p=0.002)$, and delivery of postoperative adjuvant radiation therapy $(R T)(p=0.00733)($ Table 2$)$.

\section{Overall Survival}

For all T1N0 TNBC patients, 5-year overall survival was similar for patients both with (95.7\%) and without $(92.6 \%)$ the use of adjuvant chemotherapy (Fig. 1, log-rank $p$ value $=0.077$ ). When stratified by tumor size, there was no significant improvement in survival within the subcategories of $\mathrm{T} 1 \mathrm{a}$ (5-year overall survival probability $100 \%$ v. $100 \% \mathrm{p}=0.3778$ ) and T1b (5-year overall survival probability $100 \%$ v. $95.8 \%$ $\mathrm{p}=0.2362$ ) disease. Conversely, adjuvant chemotherapy did improve overall survival for patients with T1c disease (5-year overall survival probability $93.2 \%$ v. $75.2 \% p=0.008)($ Table 3 ).

\section{Local Recurrence-Free Survival}

No significant benefit was observed in local recurrence-free survival for the entire T1N0 TNBC cohort (84.6\% with adjuvant chemotherapy v. $85.4 \%$ without, $p=0.6269$ ). When stratified by tumor size, a numeric trend was observed favoring an association between adjuvant chemotherapy and improved local recurrence-free survival with increasing tumor size, but the differences were not statistically significant: T1a (81.8\% with adjuvant chemotherapy v. 89.5\% without), T1b (95.2\% with adjuvant chemotherapy v. $87.7 \%$ without), and T1c (80.0\% with adjuvant chemotherapy v. $69.1 \%$ without) (Table 4$)$.

\section{Distant Recurrence-Free Survival}


Delivery of adjuvant chemotherapy was not significantly associated with improvements in distant recurrence-free survival for the entire T1NO TNBC cohort (91.1\% with adjuvant chemotherapy v. $89.7 \%$ without) or within the smallest-size subgroups: T1a (100\% with adjuvant chemotherapy v. $95.5 \%$ without), T1b (93.8\% with adjuvant chemotherapy v. 91.7\% without), and T1c (88.5\% with adjuvant chemotherapy v. $74.8 \%$ without). Consistent with our findings regarding adjuvant chemotherapy and overall survival endpoints, distant recurrence-free survival was numerically higher for T1c patients receiving adjuvant chemotherapy compared to those not receiving systemic treatment, but the difference did not achieve statistical significance $(88.5 \%$ versus $74.8 \% ; p=0.098)$.

\section{Impact of Adjuvant Radiotherapy (RT) and Adjuvant Chemotherapy on Overall Survival}

Table 5 demonstrates the results of multivariable Cox proportional hazards modelling to account for the effect of both adjuvant chemotherapy and adjuvant RT on overall survival. With joint modelling of both adjuvant chemotherapy and adjuvant RT, the delivery of RT did not change our results; overall survival was improved only in patients with T1c disease with receipt of adjuvant chemotherapy.

\section{Discussion}

In this multi-institutional study, we sought to determine the benefit of adjuvant chemotherapy in earlystage, node-negative TNBC. With the limitation of retrospective data, the results generated from patients treated over the last two decades at two academic medical centers demonstrated that adjuvant chemotherapy was associated with improved 5-year overall survival in patients with stage T1c nodenegative TNBC but not among those with smaller size tumors.

The high majority of screen-detected breast cancers are hormone receptor positive, resulting in a paucity of data detailing survival outcomes for cases of small, node-negative TNBC. Nonetheless, the favorable prognosis of patients with early-stage TNBC has been demonstrated by others (Table 6) [1-3, 5]. In 2012, Memorial Sloan Kettering reported a series of 194 T1a/b NO TNBC from 1999-2006 and demonstrated excellent 5-year locoregional and distant control among those that received and those that did not receive adjuvant chemotherapy [3]. Similarly, a 2014 prospective multi-institutional cohort study from the National Comprehensive Cancer Network database involving 363 T1a/b N0 TNBC patients treated 20002009 reported excellent prognosis for T1aNO and T1bN0 patients regardless of whether adjuvant CTX was delivered [2].

Most studies looking at outcomes for cases of T1NO TNBC are hampered by relatively small sample sizes of patients with T1a and T1b tumors. For example, a 2019 series of 45 TNBC and 71 hormone receptor negative/HER2 + patients with early stage, node-negative disease (T1 mi/a/bNOM0) reported no difference in survival for those receiving chemotherapy compared to those not receiving adjuvant therapy. [1]. In July 2020, An and colleagues published a single-center study of 351 TNBC patients with T1N0 disease, $88 \%$ of whom received postoperative chemotherapy. Adjuvant chemotherapy improved recurrence-free survival only in T1c disease, not in T1b and T1a. No difference in recurrence-free survival was noted for patients with T1c disease receiving different chemotherapy regimens. However, it should 
be noted that this study included only $19 \mathrm{~T} 1 \mathrm{a}$ and $67 \mathrm{~T} 1 \mathrm{~b}$ TNBC patients [4]. Ren and colleagues reported a 2019 single-institutional study of 354 triple negative T1N0 breast cancer patients and found that adjuvant chemotherapy improved recurrence-free survival for $\mathrm{T} 1 \mathrm{c}$ but not $\mathrm{T} 1 \mathrm{a}$ or $\mathrm{T} 1 \mathrm{~b}$ patients. Of note however, only seven T1a and $44 \mathrm{~T} 1 \mathrm{~b}$ patients were included in this study [6]. More recently in 2020, Zhai and colleagues reported on 7739 cases of T1NO triple negative breast cancer and also found that adjuvant chemotherapy was associated with improved overall survival only in T1c patients [7].

In an effort to address the fact that most individual studies are underpowered to detect possible benefit from adjuvant chemotherapy in patients with $\mathrm{T} 1 \mathrm{a} / \mathrm{bNO} \mathrm{TNBC}$, a nine-study meta-analysis was recently published, demonstrating that adjuvant chemotherapy was beneficial for the pooled cohort of over 750 T1bN0 patients [8]. Other national registry data from the United States and the Netherlands also indicated that adjuvant chemotherapy may improve outcomes for cases of node-negative TNBC associated with T1b tumors $[7,10]$. A limitation of the large-scale registries however, is the lack of standardized treatment approaches across the multiple institutions contributing data.

In this study, we noted that a significantly larger proportion of patients who received adjuvant chemotherapy were also recipients of postoperative adjuvant RT $(70.16 \%$ vs. $50.65 \% p=0.007)$. A recent cohort study by de Boniface et al comprised of nearly 50,000 women examined survival after breast conservation versus mastectomy. At a median follow-up of 6.28 years, they found that breast conservation therapy with RT led to improved survival compared to mastectomy.[12]. These data suggest that RT might confer a survival advantage, perhaps due to abscopal antitumor effects [13]. In our study, to address this difference regarding delivery of RT, additional analyses were performed to account for the possible survival impact. This analysis did not change our results that adjuvant chemotherapy improved overall survival in patients with $\mathrm{T} 1 \mathrm{c}$ disease but did not significantly improve outcomes in patients with $\mathrm{T} 1 \mathrm{a}$ and $\mathrm{T} 1 \mathrm{~b}$ disease.

Our study strengthens the existing literature regarding the role of adjuvant chemotherapy in early-stage TNBC because we evaluated the management of patients seen in two large tertiary referral cancer programs featuring similar multidisciplinary management teams. Both of these sites are certified by the National Accreditation Program for Breast Centers. We found that node-negative TNBC patients with tumors no larger than one centimeter have excellent survival rates and may be spared the toxicity of systemic therapy. Clinical judgement regarding cases associated with higher-risk features (e.g. young age at diagnosis; histologic features consistent with more aggressive disease such as metaplasia) remains important in individualizing treatment plans.

\section{Limitations}

There are several limitations inherent to our study, given its retrospective nature and the prolonged time period during which data were collected as adjuvant chemotherapy regimens have evolved. We also acknowledge the small sample sizes of subsets within the T1N0 category, albeit larger than those reported in several other studies. Regarding the possible effect of RT, we recognize that our sample size precluded exploration of the possibility that adjuvant RT may confer a survival advantage. Our analysis 
was also limited by inability to provide details regarding chemotherapy schedules and content. Lastly, we recognize that given the retrospective nature of our study, selection bias may exist regarding which patients were offered adjuvant chemotherapy. We did not collect data regarding performance status and comorbidities and therefore cannot ascertain whether this may account for the overall benefit seen among patients with larger tumors.

\section{Conclusion}

Our findings support current guidelines indicating benefit from adjuvant chemotherapy in node-negative TNBC associated with T1c tumors. We found excellent survival outcomes in T1a/b node-negative patients regardless of whether adjuvant chemotherapy was delivered. Additional research is necessary regarding more precise methods to risk-stratify patients with node-negative TNBC and tumors no larger than one centimeter in size.

\section{Declarations}

Funding: Dr. Newman receives funding from Susan G. Komen and the Fashion Footwear Association of New York Charitable Foundation

Conflicts of interest/Competing interests: Not applicable

Availability of data and material: The datasets generated during and/or analyzed during the current study are available from the corresponding author on reasonable request.

Code availability: Not applicable

Ethics approval; Not applicable

Consent to participate: Not applicable

Consent for publication: Consent for publication of the work contained in the manuscript was obtained by all authors.

\section{Conflict of Interest Summary Statement}

Conflict of Interest: The authors declare that they have no conflict of interest.

\section{References}

1. Bao J, Donovan C, Amersi F, Zhang X, Giuliano AE, Chung A (2019) Outcomes in patients with small node-negative invasive breast cancer. Breast J 25(4):638-643. https://doi.org/10.1111/tbj.13288

2. Vaz-Luis I, Ottesen RA, Hughes ME, Mamet R, Burstein HJ, Edge SB, Gonzalez-Angulo AM, Moy B, Rugo HS, Theriault RL, Weeks JC, Winer EP, Lin NU (2014) Outcomes by tumor subtype and treatment 
pattern in women with small, node-negative breast cancer: a multi-institutional study. J Clin Oncol 32(20):2142-2150. https://doi.org/10.1200/jco.2013.53.1608

3. Ho AY, Gupta G, King TA, Perez CA, Patil SM, Rogers KH, Wen YH, Brogi E, Morrow M, Hudis CA, Traina T, McCormick B, Powell SN, Robson ME (2012) Favorable prognosis in patients with T1a/T1bN0 triple-negative breast cancers treated with multimodality therapy. Cancer 118(20):4944-4952. https://doi.org/10.1002/cncr.27480

4. An X, Lei X, Huang R, Luo R, Li H, Xu F, Yuan Z, Wang S, de Nonneville A, Gonçalves A, Houvenaeghel G, Li J, Xue C, Shi Y (2020) Adjuvant chemotherapy for small, lymph node-negative, triple-negative breast cancer: A single-center study and a meta-analysis of the published literature. Cancer Suppl 16:3837-3846. https://doi.org/10.1002/cncr.32878

5. Colonna SV, Higgins AK, Alvarez J, Saville BR, Lawrence J, Abramson VG (2015) Analysis of Risk of Recurrence by Subtype in $\leq 1-\mathrm{cm}$ Breast Tumors. Clin Breast Cancer 16(3):223-231. https://doi.org/10.1016/j.clbc.2015.10.001

6. Ren YX, Hao S, Jin X, Ye FG, Gong Y, Jiang YZ, Shao ZM (2019) Effects of adjuvant chemotherapy in T1N0M0 triple-negative breast cancer. Breast 43:97-104.

https://doi.org/10.1016/j.breast.2018.11.011

7. Zhai Z, Zheng Y, Yao J, Liu Y, Ruan J, Deng Y, Zhou L, Zhao P, Yang S, Hu J, We B, Wu Y, Zhang D, Kang H, Dai Z (2020) Evaluation of Adjuvant Treatments for T1 NO MO Triple-Negative Breast Cancer. JAMA Netw Open 3(11):e2021881. https://doi.org/10.1001/jamanetworkopen.2020.21881

8. Yang Z, Chen Y, Liu X, Cui J, Hu Y, Wei W (2020) Effects of adjuvant chemotherapy on recurrence rate in T1abNOMO triple-negative breast cancer: A meta-analysis. Cancer Treat Res Commun 25:100211. https://doi.org/10.1016/j.ctarc.2020.100211

9. Jauhari Y, Dodwell D, Gannon MR, Horgan K, Clements K, Medina J, Cromwell DA (2020) The influence of age, comorbidity and frailty on treatment with surgery and systemic therapy in older women with operable triple negative breast cancer (TNBC) in England: A population-based cohort study. Eur J Surg Oncol S0748-7983(20)30794-0. https://doi.org/10.1016/j.ejso.2020.09.022

10. Steenbruggen TG, van Werkhoven E, van Ramshorst MS, Dezentjé VO, Kok M, Linn SC, Siesling S, Sonke GS (2020) Adjuvant chemotherapy in small node-negative triple-negative breast cancer. Eur J Cancer 135:66-74. https://doi.org/10.1016/j.ejca.2020.04.033

11. Syed BM, Green AR, Nolan CC, Morgan DA, Ellis IO, Cheung KL (2014) Biological characteristics and clinical outcome of triple negative primary breast cancer in older women - comparison with their younger counterparts. PLoS One 9(7):e100573. https://doi.org/10.1371/journal.pone.0100573

12. De Boniface J, Szulkin R, Johansson A (2021) Survival after breast conservation vs mastectomy adjusted for comorbidity and socioeconomic status: a Swedish national 6-year follow-up of 48986 women. JAMA Surgery. https://doi.org/10.1001/jamasurg.2021.1438

13. Newman LA (2021) Safety of breast-conserving surgery in breast cancer and risk of overtreatment vs undertreatment. JAMA Surgery. https://doi.org/10.1001/jamasurg.2021.1450 


\section{Tables}

Page 10/18 
Table 1

Characteristics of T1NO TNBC patients stratified by site (HFHS = Henry Ford Health System and WCM $=$ Weill Cornell Medicine)

\begin{tabular}{|c|c|c|c|c|}
\hline & & HFHS ( $n=84)$ & WCM $(n=198)$ & $P$ value \\
\hline \multirow[t]{3}{*}{ Race } & African American & $48(57.1 \%)$ & $22(11.1 \%)$ & \multirow{3}{*}{$<0.0001$} \\
\hline & White American & $36(42.9 \%)$ & $140(70.7 \%)$ & \\
\hline & NA & $0(0 \%)$ & $36(18.2 \%)$ & \\
\hline \multirow[t]{2}{*}{ Age 50} & $\leq 50$ & $14(16.7 \%)$ & $54(27.3 \%)$ & \multirow[t]{2}{*}{0.0798} \\
\hline & $>50$ & $70(83.3 \%)$ & $144(72.7 \%)$ & \\
\hline \multirow[t]{6}{*}{ Histology } & IDC & $71(84.5 \%)$ & $185(93.43 \%)$ & \multirow[t]{6}{*}{$<0.0001$} \\
\hline & IDC/ILC & $7(8.33 \%)$ & $0(0 \%)$ & \\
\hline & ILC & $5(5.95 \%)$ & $3(1.51 \%)$ & \\
\hline & Metaplastic & $0(0 \%)$ & $3(1.51 \%)$ & \\
\hline & Other & $0(0 \%)$ & $6(3.03 \%)$ & \\
\hline & Unknown & $1(1.19 \%)$ & $1(0.50 \%)$ & \\
\hline \multirow[t]{3}{*}{ Any high-grade disease } & No & $22(26.1 \%)$ & $30(15.15 \%)$ & \multirow[t]{3}{*}{0.048} \\
\hline & Yes & $60(71.4 \%)$ & $161(81.31 \%)$ & \\
\hline & Unknown & $2(2.38 \%)$ & $7(3.54 \%)$ & \\
\hline \multirow[t]{3}{*}{ Any LVI } & No & 77 (91.7\%) & $141(71.2 \%)$ & \multirow[t]{3}{*}{0.119} \\
\hline & Yes & $6(7.14 \%)$ & $25(12.63 \%)$ & \\
\hline & Unknown & $1(1.19 \%)$ & $32(16.16 \%)$ & \\
\hline \multirow[t]{2}{*}{ Mastectomy } & No & $62(73.8 \%)$ & $131(66.2 \%)$ & \multirow[t]{2}{*}{0.261} \\
\hline & Yes & $22(26.2 \%)$ & 67 (33.8\%) & \\
\hline \multirow[t]{3}{*}{ CPM } & No & $79(94.0 \%)$ & $159(80.30 \%)$ & \multirow[t]{3}{*}{0.00357} \\
\hline & Yes & $4(4.76 \%)$ & 38 (19.19\%) & \\
\hline & Unknown & $1(1.19 \%)$ & $1(0.50 \%)$ & \\
\hline \multirow[t]{3}{*}{ Adjuvant XRT } & Breast & $56(66.7 \%)$ & $111(56.06 \%)$ & \multirow[t]{3}{*}{0.917} \\
\hline & Breast/Regional & $1(1.19 \%)$ & $2(1.01 \%)$ & \\
\hline & None & $26(30.9 \%)$ & $53(26.77 \%)$ & \\
\hline
\end{tabular}




\begin{tabular}{|c|c|c|c|c|}
\hline & & HFHS ( $n=84)$ & WCM $(n=198)$ & $P$ value \\
\hline & PMRT & $0(0 \%)$ & $1(0.50 \%)$ & \\
\hline & Unknown & $1(1.19 \%)$ & $31(15.66 \%)$ & \\
\hline \multirow[t]{3}{*}{ Pathologic T Stage } & T1a & $7(8.3 \%)$ & $34(17.17 \%)$ & \multirow[t]{3}{*}{0.115} \\
\hline & $\mathrm{T} 1 \mathrm{~b}$ & $27(32.1 \%)$ & $66(33.33 \%)$ & \\
\hline & T1c & $50(59.5 \%)$ & $98(49.49 \%)$ & \\
\hline \multirow[t]{3}{*}{ Adjuvant Chemotherapy } & No & $19(22.6 \%)$ & $58(29.29 \%)$ & \multirow[t]{3}{*}{0.146} \\
\hline & Yes & $63(75.0 \%)$ & $118(59.60 \%)$ & \\
\hline & Unknown & $2(2.38 \%)$ & 22 (11.11\%) & \\
\hline
\end{tabular}


Table 2

Characteristics of 258 T1NO TNBC patients stratified by receipt of adjuvant chemotherapy

\begin{tabular}{|c|c|c|c|c|}
\hline & & $\begin{array}{l}\text { No Adjuvant } \\
\text { Chemotherapy } \\
(n=77)\end{array}$ & $\begin{array}{l}\text { Adjuvant } \\
\text { Chemotherapy }(n= \\
181)\end{array}$ & $P$ value \\
\hline Age at Diagnosis & & $64(38,92)$ & $61(29,85)$ & 0.0035 \\
\hline \multirow[t]{3}{*}{ Race } & $\begin{array}{l}\text { African } \\
\text { American }\end{array}$ & 15 (19.5\%) & $51(28.2 \%)$ & \multirow[t]{3}{*}{0.155} \\
\hline & White & $54(70.1 \%)$ & $108(59.7 \%)$ & \\
\hline & NA & $8(10.4 \%)$ & $22(12.2 \%)$ & \\
\hline \multirow[t]{2}{*}{ Age 50} & $\leq 50$ & $10(13.0 \%)$ & $54(29.8 \%)$ & \multirow[t]{2}{*}{0.0067} \\
\hline & $>50$ & 67 (87.0\%) & $127(70.2 \%)$ & \\
\hline \multirow[t]{6}{*}{ Histology } & IDC & 67 (87.01\%) & 168 (92.82\%) & \multirow[t]{6}{*}{0.0337} \\
\hline & IDC/ILC & $3(3.90 \%)$ & $4(2.21 \%)$ & \\
\hline & ILC & $2(2.60 \%)$ & $3(1.66 \%)$ & \\
\hline & Metaplastic & $0(0 \%)$ & $3(1.66 \%)$ & \\
\hline & Other & $5(6.49 \%)$ & $1(0.55 \%)$ & \\
\hline & Unknown & $0(0 \%)$ & $2(1.10 \%)$ & \\
\hline \multirow{3}{*}{$\begin{array}{l}\text { Any High-Grade } \\
\text { Disease }\end{array}$} & No & $24(31.17 \%)$ & $25(13.81 \%)$ & \multirow[t]{3}{*}{0.00169} \\
\hline & Yes & $50(64.94 \%)$ & 151 (83.43\%) & \\
\hline & Unknown & $3(3.90 \%)$ & $5(2.76 \%)$ & \\
\hline \multirow[t]{3}{*}{ Any LVI } & No & $63(81.82 \%)$ & 137 (75.69\%) & \multirow[t]{3}{*}{0.332} \\
\hline & Yes & $6(7.79 \%)$ & $23(12.71 \%)$ & \\
\hline & Unknown & $8(10.39 \%)$ & $21(11.60 \%)$ & \\
\hline \multirow[t]{2}{*}{ Mastectomy } & No & $46(59.7 \%)$ & $127(70.2 \%)$ & \multirow[t]{2}{*}{0.137} \\
\hline & Yes & $31(40.3 \%)$ & $54(29.8 \%)$ & \\
\hline \multirow[t]{3}{*}{ CPM } & No & $67(87.0 \%)$ & $148(81.8 \%)$ & \multirow[t]{3}{*}{0.496} \\
\hline & Yes & $10(13.0 \%)$ & $31(17.1 \%)$ & \\
\hline & Unknown & $0(0 \%)$ & $2(1.1 \%)$ & \\
\hline $\begin{array}{l}\text { Adjuvant Radiation } \\
\text { Therapy }\end{array}$ & Breast & 37 (48.05\%) & 125 (69.06\%) & 0.00733 \\
\hline
\end{tabular}




\begin{tabular}{|c|c|c|c|c|}
\hline & & $\begin{array}{l}\text { No Adjuvant } \\
\text { Chemotherapy } \\
(n=77)\end{array}$ & $\begin{array}{l}\text { Adjuvant } \\
\text { Chemotherapy }(n= \\
181)\end{array}$ & $P$ value \\
\hline & Breast/Regional & $2(2.60 \%)$ & $1(0.55 \%)$ & \\
\hline & PMRT & $0(0 \%)$ & $1(0.55 \%)$ & \\
\hline & None & $33(42.85 \%)$ & $45(24.86 \%)$ & \\
\hline & Unknown & $5(6.94 \%)$ & $9(4.97 \%)$ & \\
\hline \multirow[t]{3}{*}{ Pathologic T Stage } & $\mathrm{T} 1 \mathrm{a}$ & $25(32.47 \%)$ & $11(6.08 \%)$ & \multirow{3}{*}{$\begin{array}{l}< \\
0.0001\end{array}$} \\
\hline & $\mathrm{T} 1 \mathrm{~b}$ & $30(38.96 \%)$ & 55 (30.39\%) & \\
\hline & T1c & $22(28.57 \%)$ & $115(63.5 \%)$ & \\
\hline
\end{tabular}

Table 3

5-year overall survival probability of $\mathrm{T} 1, \mathrm{~T} 1 \mathrm{a}, \mathrm{T} 1 \mathrm{~b}$, and $\mathrm{T} 1 \mathrm{c}$ node-negative $\mathrm{TNBC}$ patients treated with and without adjuvant chemotherapy (CTX)

\begin{tabular}{|c|c|c|c|c|c|}
\hline Stage & & $\begin{array}{l}\text { 5-year survival } \\
\text { probability } \\
\text { (\%) }\end{array}$ & Hazard Ratio & $\begin{array}{l}\text { Number of } \\
\text { patients }\end{array}$ & $P$ value \\
\hline \multirow[t]{2}{*}{$\mathrm{T} 1$} & $\begin{array}{l}\text { No adjuvant } \\
\text { CTX }\end{array}$ & 92.6 & 1.0 & 90 & \multirow[t]{2}{*}{0.07656} \\
\hline & Adjuvant CTX & 95.7 & $0.4(0.14-1.14)$ & 182 & \\
\hline \multirow[t]{2}{*}{ T1a } & $\begin{array}{l}\text { No adjuvant } \\
\text { CTX }\end{array}$ & 100 & 1.0 & 25 & \multirow[t]{2}{*}{0.3778} \\
\hline & Adjuvant CTX & 100 & $\begin{array}{l}7.77 e-10(0.0- \\
\text { Inf) }\end{array}$ & 11 & \\
\hline \multirow[t]{2}{*}{$\mathrm{T} 1 \mathrm{~b}$} & $\begin{array}{l}\text { No adjuvant } \\
\text { CTX }\end{array}$ & 95.8 & 1.0 & 30 & \multirow[t]{2}{*}{0.2362} \\
\hline & Adjuvant CTX & 100 & $\begin{array}{l}0.26(0.0236- \\
2.87)\end{array}$ & 55 & \\
\hline \multirow[t]{2}{*}{ T1c } & $\begin{array}{l}\text { No adjuvant } \\
\text { CTX }\end{array}$ & 75.2 & 1.0 & 22 & \multirow[t]{2}{*}{0.00768} \\
\hline & Adjuvant CTX & 93.2 & $\begin{array}{l}0.208(0.0579- \\
0.744)\end{array}$ & 115 & \\
\hline
\end{tabular}


Table 4

5-year local recurrence-free survival probability of $\mathrm{T} 1, \mathrm{~T} 1 \mathrm{a}, \mathrm{T} 1 \mathrm{~b}$, and $\mathrm{T} 1 \mathrm{c}$ node-negative TNBC patients treated with and without adjuvant chemotherapy (CTX)

\begin{tabular}{|c|c|c|c|c|c|}
\hline \multicolumn{2}{|c|}{ Stage } & \multirow{2}{*}{$\begin{array}{l}\text { 5-year survival } \\
\text { probability } \\
85.4\end{array}$} & \multirow{2}{*}{$\begin{array}{l}\text { Hazard Ratio } \\
1.0\end{array}$} & \multirow{2}{*}{$\begin{array}{l}\text { Number of } \\
\text { patients } \\
90\end{array}$} & \multirow{2}{*}{$\begin{array}{l}P \\
\text { value } \\
0.6269\end{array}$} \\
\hline T1 & $\begin{array}{l}\text { No adjuvant } \\
\text { CTX }\end{array}$ & & & & \\
\hline & Adjuvant CTX & 84.6 & $\begin{array}{l}0.844(0.425- \\
1.68)\end{array}$ & 182 & \\
\hline \multirow[t]{2}{*}{ T1a } & $\begin{array}{l}\text { No adjuvant } \\
\text { CTX }\end{array}$ & 89.5 & 1.0 & 25 & 0.9856 \\
\hline & Adjuvant CTX & 81.8 & 0.983 & 11 & \\
\hline \multirow[t]{2}{*}{ T1b } & $\begin{array}{l}\text { No adjuvant } \\
\text { CTX }\end{array}$ & 87.8 & 1.0 & 30 & 0.160 \\
\hline & Adjuvant CTX & 95.2 & $0.358(0.08-1.6)$ & 55 & \\
\hline \multirow[t]{2}{*}{ T1c } & $\begin{array}{l}\text { No adjuvant } \\
\text { CTX }\end{array}$ & 69.1 & 1.0 & 22 & 0.1506 \\
\hline & Adjuvant CTX & 80 & $\begin{array}{l}0.492(0.183- \\
1.32)\end{array}$ & 115 & \\
\hline
\end{tabular}

Table 5

Multivariable Cox proportional hazard modelling of adjuvant chemotherapy (CTX) and adjuvant RT on 5-year overall survival in T1NO TNBC

\begin{tabular}{|lllll|}
\hline Stage & & Hazard Ratio & $95 \%$ Confidence Interval & P value \\
\hline T1 & Adjuvant RT & 0.41 & $0.13-1.2$ & 0.112 \\
\cline { 2 - 5 } & Adjuvant CTX & 0.41 & $0.13-1.2$ & 0.113 \\
\hline T1a & Adjuvant RT & $6.4 \mathrm{E}-10$ & $0.0-$ Inf & 1 \\
\cline { 2 - 5 } & Adjuvant CTX & $1.4 \mathrm{E}-09$ & $0.0-\operatorname{Inf}$ & 1 \\
\hline T1b & Adjuvant RT & 0.23 & $0.021-2.6$ & 0.234 \\
\cline { 2 - 5 } & Adjuvant CTX & 0.25 & $0.023-2.8$ & 0.257 \\
\hline T1c & Adjuvant RT & 0.66 & $0.164-2.62$ & 0.5512 \\
\cline { 2 - 5 } & Adjuvant CTX & 0.21 & $0.053-0.86$ & 0.0292 \\
\cline { 2 - 5 }
\end{tabular}


Table 6

Adjuvant chemotherapy (CTX) in early-stage triple negative breast cancer outcome studies

\begin{tabular}{|c|c|c|c|c|}
\hline Study & Patient Sample & $\begin{array}{l}\text { Median } \\
\text { Follow- } \\
\text { Up }\end{array}$ & Timeline & Adjuvant CTX Survival Benefit? \\
\hline Ho (2012) & $\begin{array}{l}\text { 194 } 1 \text { cm node- } \\
\text { negative TNBC } \\
\text { T1mic: } 16 \\
\text { T1a: } 49 \\
\text { T1b: } 129 \\
\text { Memorial Sloan } \\
\text { Kettering Cancer Center } \\
\text { (MSKCC) }\end{array}$ & $\begin{array}{l}73 \\
\text { months }\end{array}$ & $\begin{array}{l}1999- \\
2006\end{array}$ & $\begin{array}{l}\text { T1mic/T1a: No } \\
\text { T1b: No }\end{array}$ \\
\hline $\begin{array}{l}\text { Vaz-Luis } \\
\text { (2014) }\end{array}$ & $\begin{array}{l}363 \text { T1a,bNOMO TNBC } \\
\text { T1a: } 99 \\
\text { T1b: } 264 \\
\text { National } \\
\text { Comprehensive Cancer } \\
\text { Network }\end{array}$ & $\begin{array}{l}5.5 \\
\text { years }\end{array}$ & $\begin{array}{l}2000- \\
2009\end{array}$ & $\begin{array}{l}\text { T1a/b: } 5 \text {-year OS } 91-94 \% \text { in } \\
\text { patients without CTX and } 96- \\
100 \% \text { in patients with CTX }\end{array}$ \\
\hline $\begin{array}{l}\text { Colonna } \\
\text { (2016) }\end{array}$ & $\begin{array}{l}49 \text { T1a-bNO TNBC } \\
\text { T1a: } 11 \\
\text { T1b: } 38 \\
\text { Vanderbilt and Wake } \\
\text { Forest }\end{array}$ & $\begin{array}{l}6.2 \\
\text { years }\end{array}$ & $\begin{array}{l}1997- \\
2009\end{array}$ & T1a/b: No \\
\hline Ren (2019) & $\begin{array}{l}354 \text { T1N0M0 TNBC } \\
\text { T1a: } 7 \\
\text { T1b: } 44 \\
\text { T1c: } 303 \\
\text { Fudan University } \\
\text { Shanghai Cancer } \\
\text { Center }\end{array}$ & $\begin{array}{l}45 \\
\text { months }\end{array}$ & $\begin{array}{l}2008- \\
2015\end{array}$ & $\begin{array}{l}\text { T1a: NA }(n=7) \\
\text { T1b: No } \\
\text { T1c: Yes }\end{array}$ \\
\hline Bao (2019) & $\begin{array}{l}45 \text { patients with } \\
\text { pT1mi,a,b,NOM0 TNBC } \\
\text { T1mi: } 4 \\
\text { T1a: } 9 \\
\text { T1b: } 32 \\
\text { Cedars-Sinai Medical } \\
\text { Center }\end{array}$ & $\begin{array}{l}4.9 \\
\text { years }\end{array}$ & $\begin{array}{l}2000- \\
2013\end{array}$ & $\begin{array}{l}\text { T1mi: No } \\
\text { T1a: No } \\
\text { T1b: No }\end{array}$ \\
\hline An (2020) & $\begin{array}{l}351 \text { pT1N0M0 TNBC } \\
\text { T1a: } 19 \\
\text { T1b: } 67 \\
\text { T1c: } 265 \\
\text { Sun Yat-Sen University } \\
\text { Cancer Center }\end{array}$ & $\begin{array}{l}68.5 \\
\text { months }\end{array}$ & $\begin{array}{l}2000- \\
2016\end{array}$ & $\begin{array}{l}\text { T1a/b: No } \\
\text { T1c: Yes }\end{array}$ \\
\hline
\end{tabular}




\begin{tabular}{|c|c|c|c|c|}
\hline Study & Patient Sample & $\begin{array}{l}\text { Median } \\
\text { Follow- } \\
\text { Up }\end{array}$ & Timeline & Adjuvant CTX Survival Benefit? \\
\hline Zhai (2020) & $\begin{array}{l}7739 \text { patients with } \\
\text { T1N0M0 TNBC } \\
\text { T1a: } 755 \\
\text { T1b: } 1979 \\
\text { T1c: } 5005 \\
\text { SEER database }\end{array}$ & $\begin{array}{l}45 \\
\text { months }\end{array}$ & $\begin{array}{l}2010- \\
2015\end{array}$ & $\begin{array}{l}\text { In T1N0, adjuvant CTX } \\
\text { associated with significantly } \\
\text { better BCSS }\end{array}$ \\
\hline $\begin{array}{l}\text { Steenbruggen } \\
(2020)\end{array}$ & $\begin{array}{l}4366 \text { pT1N0M0 TNBC } \\
\text { patients } \\
\text { T1a: } 284 \\
\text { T1b: } 923 \\
\text { T1c: } 3159 \\
\text { Netherlands Cancer } \\
\text { Registry }\end{array}$ & $\begin{array}{l}8.2 \\
\text { years }\end{array}$ & $\begin{array}{l}2005- \\
2016\end{array}$ & $\begin{array}{l}\text { T1a/b: Yes } \\
\text { T1c: Yes with better outcome } \\
\text { most evident in T1c }\end{array}$ \\
\hline $\begin{array}{l}\text { Fasano } \\
(2021)\end{array}$ & $\begin{array}{l}258 \text { T1N0 TNBC } \\
\text { T1a: } 36 \\
\text { T1b: } 85 \\
\text { T1c: } 137 \\
\text { Weill Cornell Medicine } \\
\text { and Henry Ford Health } \\
\text { System }\end{array}$ & $\begin{array}{l}4.7 \\
\text { years }\end{array}$ & $\begin{array}{l}1998- \\
2018\end{array}$ & $\begin{array}{l}\text { T1a/b: No } \\
\text { T1c: Yes }\end{array}$ \\
\hline
\end{tabular}

\section{Figures}



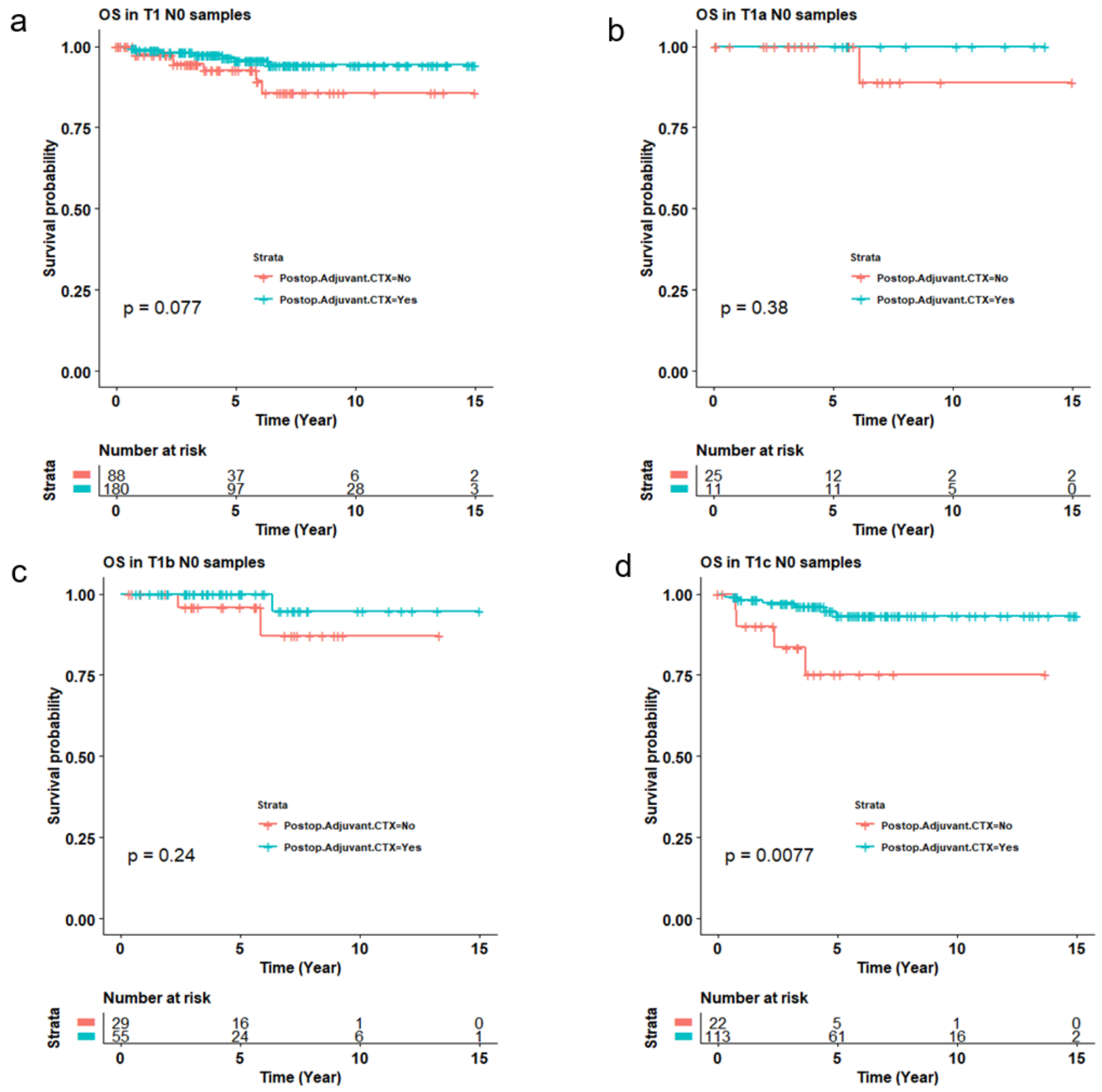

\section{Figure 1}

Overall survival of T1NO TNBC patients treated with and without adjuvant chemotherapy stratified by tumor size a) T1N0 b) T1aN0 c) T1bN0 d) T1cN0 Note: Figure created utilizing statistical programming language $\mathrm{R}$ version 3.6.1 (R Foundation for Statistical Computing). 